DOI 10.32900/2312-8402-2020-123-9-20

УДК 577.15: 58.085: 58.089: 636.028

\title{
ANTIOXIDANT ACTIVITY OF VEGETATIVE ORGANS OF DENDROBIUM PARISHII RCHB.F. IN THE MUSCLE TISSUE OF RAINBOW TROUT (ONCORHYNCHUS MYKISS WALBAUM): IN VITRO MODEL STUDY
}

\author{
Buyun L., Doctor of Biological Sciences \\ Gyrenko O., a post-graduate student \\ Opryshko M., a post-graduate student \\ Kovalska L., Ph.D.
}

M. M. Gryshko National Botanic Garden, National Academy of Science of Ukraine,

Tkachenko H., Doctor of Biological Sciences

Kurhaluk N., Doctor of Biological Sciences

Institute of Biology and Earth Sciences, Pomeranian University in Słupsk

This research aimed to evaluate the in vitro effect of buffer extract obtained from leaves and pseudobulbs (modified shoots) of Dendrobium parishii Rchb. $f$. on the 2-thiobarbituric acid reactive substances (TBARS) as lipid peroxidation biomarker, aldehydic and ketonic derivatives of oxidatively modified proteins, and total antioxidant capacity (TAC) in the muscle tissue of the rainbow trout (Oncorhynchus mykiss Walbaum). The shoots (pseudobulbs) with leaves of Dendrobium parishii cultivated under glasshouse conditions were sampled at M.M. Gryshko National Botanic Garden (NBG) (Kyiv, Ukraine). Since 1999, the whole collection of tropical and subtropical plants (including orchids) has had the status of a National Heritage Collection of Ukraine and is supported through State funding. Besides, NBG's collection of tropical orchids was registered at the Administrative Organ of CITES in Ukraine (Ministry of Environment Protection, registration No. 6939/19/1-10 of 23 June 2004). The collected pseudobulbs and leaves were brought into the laboratory for biochemical studies. Freshly collected leaves were washed, weighed, crushed, and homogenized in 0.1M phosphate buffer ( $\mathrm{pH}$ 7.4) (in proportion 1:19, w/w) at room temperature. The extract was then filtered and investigated for its antioxidant capacity. The extract was stored at $-20^{\circ} \mathrm{C}$ until use. The increase in TBARS level in the muscle tissue exposed to extracts derived from leaves and pseudobulbs of D. parishii was insignificant. The level of ketonic derivatives of oxidatively modified proteins was non-significantly decreased both for leaf and pseudobulb extracts compared to the untreated samples. The extracts obtained from leaves and pseudobulbs of D. parishii significantly increased the TAC level in muscle tissue due to inhibited the $\mathrm{Fe}^{2+} /$ ascorbate-induced oxidation of Tween 80. Overall, these findings demonstrate that aqueous extracts of vegetative organs of Dendrobium parishii can enhance the total antioxidant capacity in the muscle tissue of the rainbow trout. Moreover, this antioxidant effect was more intensive for pseudobulb extracts.

Keywords: Dendrobium Sw., extracts, antioxidant activity, muscle tissue, rainbow trout (Oncorhynchus mykiss Walbaum)

Growing attention in the recent decade has been paid to medicinal plants as promising and substitute agents for the control of fish disease in aquaculture that offers an alternative, because of their immunomodulatory effects, to the drugs, chemicals, and antibiotics currently used in aquaculture to manage diseases in commercially farmed fish [9]. The mechanisms of action of plants and their derivatives are attributed to the presence of many active secondary metabolites such as alkaloids, steroids, phenolics, 
tannins, terpenoids, saponins, glycosides, and flavonoids $[6,9,10]$. The use of synthetic antioxidants in aquaculture has been associated with numerous side effects (immunosuppression in fish, human carcinogenicity risk, etc.) [26], thereby necessitating a further search for alternative sources of antioxidants such as natural products. Therefore, the development of new additives for aquaculture still attracts the attention of many researchers and fish farmers comprising the eco-friendly approach for the control of fish pathogens.

Dendrobium species are important commercial plants widely used as herbal medicines for hundreds of years in China due to their pharmacological properties [5, 15]. Recently, within the Dendrobium genus, most studies have focused on the bioactivity and structural types of some small molecules, such as bibenzyl, phenanthrene, anthracene, fluorene, coumarin, flavone, cinnamate, sesquiterpene, sterol, fatty acid, and alkaloids [11, 24, 31]. Alkaloids exhibit antioxidant, anticancer, and neuroprotective activities. Specifically, the protective effect of Dendrobium alkaloids (DNLA), a Chinese medicinal herb extract, inhibiting neuronal apoptosis, and preventing synaptic loss has been investigated by Nie and co-workers (2016) in mice [22]. Also, Dendrobium alkaloids have been reported to exert therapeutic effects against cataracts, retinal inflammation, and fungi-induced inflammation [18]. Other compounds manifest antioxidant, anticancer, and immunomodulatory [21]. In the past decades, D. nobile Lindl. has been used to treat tumors, hyperglycemia, hyperlipidemia, and diseases of the nervous system that may be associated with aging [23].

In our previous study, the level of oxidative stress biomarkers [2-thiobarbituric acid reactive substances (TBARS), carbonyl derivatives content of protein oxidative modification, total antioxidant capacity] in the equine plasma and erythrocytes after treatment with Dendrobium parishii Rchb. f. leaf extract was assessed. The TBARS content as a biomarker of lipid peroxidation, aldehydic and ketonic derivatives level, as well as total antioxidant capacity, was non-significantly altered in the erythrocyte suspensions after in vitro incubation with an extract obtained from $D$. parishii. More significant changes were observed in the plasma. The D. parishii extract caused to increase in the formation of intracellular aldehydic and ketonic derivatives of oxidatively modified proteins in the extract-treated plasma, but these results were non-significant. Total antioxidant capacity was non-significant decreased both in plasma and erythrocytes. Screening of Dendrobium plants for other biological activities including antioxidant activities is essential and may be effective for searching the preventive agents in the pathogenesis of some metabolic diseases [3].

Thus, our research aimed to evaluate the in vitro effect of buffer extract obtained from leaves of Dendrobium parishii Rchb. f. on the 2-thiobarbituric acid reactive substances (TBARS) as lipid peroxidation biomarker, aldehydic and ketonic derivatives of oxidatively modified proteins, and total antioxidant capacity (TAC) in the muscle tissue of the rainbow trout (Oncorhynchus mykiss Walbaum).

Materials and Methods. Collection of Plant Materials and Preparation of Plant Extracts. The shoots (pseudobulbs) with leaves of Dendrobium parishii cultivated under glasshouse conditions were sampled at M.M. Gryshko National Botanic Garden (NBG) (Kyiv, Ukraine) (Photo 1). Since 1999, the whole collection of tropical and subtropical plants (including orchids) has had the status of a National Heritage Collection of Ukraine and is supported through State funding. Besides, NBG's collection of tropical orchids was registered at the Administrative Organ of CITES in Ukraine (Ministry of Environment Protection, registration No. 6939/19/1-10 of 23 June 2004). The collected pseudobulbs and leaves were brought into the laboratory for biochemical studies. Freshly collected leaves were washed, weighed, crushed, and homogenized in $0.1 \mathrm{M}$ 
phosphate buffer ( $\mathrm{pH}$ 7.4) (in proportion 1:19, w/w) at room temperature. The extract was then filtered and investigated for its antioxidant capacity. The extract was stored at $-20^{\circ} \mathrm{C}$ until use.

Experimental fish. Clinically healthy rainbow trout with a mean body mass of 80-120 $\mathrm{g}$ were used in the experiments. The experiments were performed in water at $14.5 \pm 0.5^{\circ} \mathrm{C}$ and $\mathrm{pH} 7.2-7.4$. The dissolved oxygen level was about $9 \mathrm{ppm}$ with additional oxygen supply, with a water flow of $25 \mathrm{~L} / \mathrm{min}$, and a photoperiod of $12 \mathrm{~h}$ per day. The water parameters were maintained under constant surveillance. The fish were held in square tanks (150 fish per tank) and fed commercial pelleted diet.

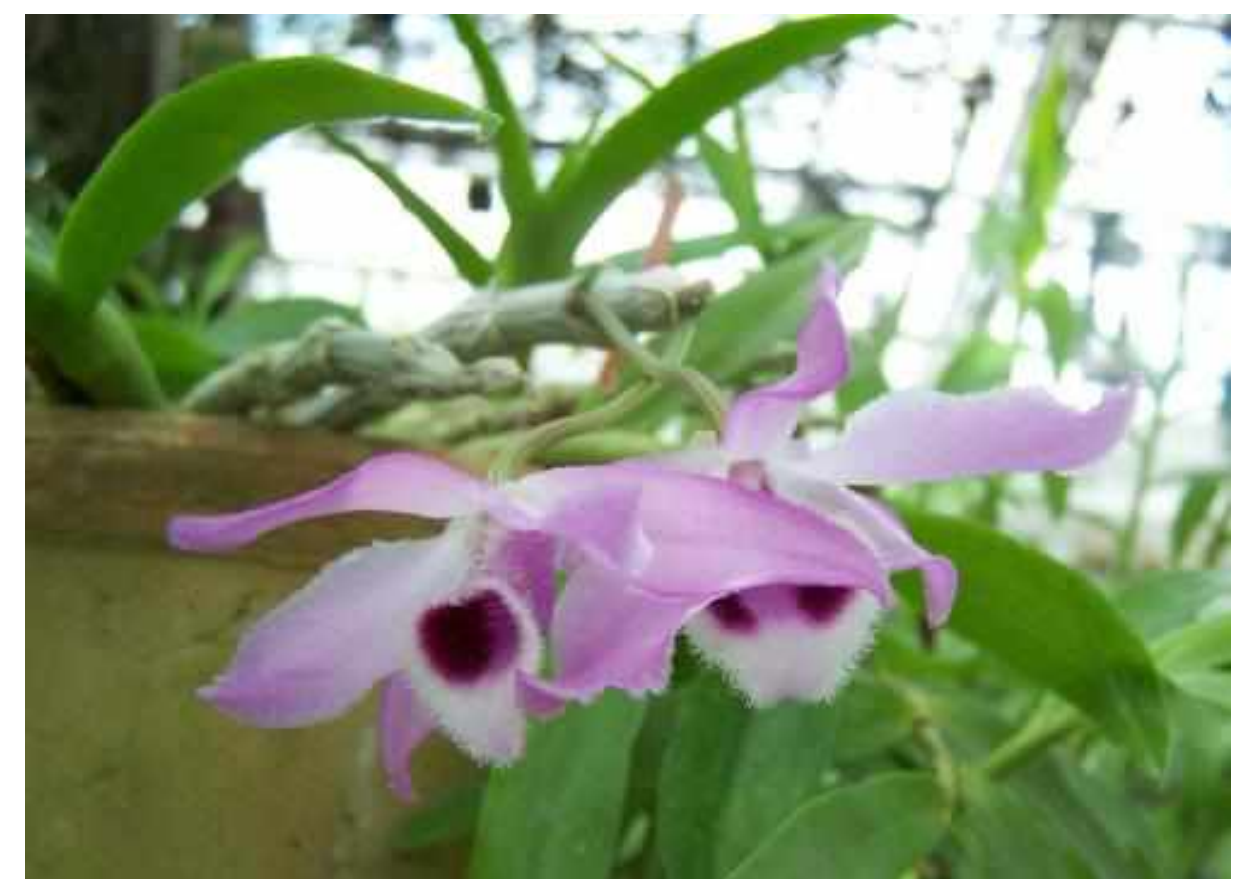

Photo 1. Dendrobium parishii Lindl. plant, cultivated at NBG's glasshouses (Kyiv, Ukraine). Photo: Lyudmyla I. Buyun

Muscle tissue samples. The muscle tissue samples were homogenized in icecold buffer (100 mM Tris-HCl, $\mathrm{pH}$ 7.2) using a glass homogenizer immersed in an ice water bath. Homogenates were centrifuged at $3,000 \mathrm{~g}$ for $15 \mathrm{~min}$ at $4^{\circ} \mathrm{C}$. After centrifugation, the supernatant was collected and frozen at $-20^{\circ} \mathrm{C}$ until analyzed. All enzymatic assays were carried out at $22 \pm 0.5^{\circ} \mathrm{C}$ using a Specol 11 spectrophotometer (Carl Zeiss Jena, Germany) in duplicate. The reactions were started by adding the tissue supernatant.

Experimental design. The supernatant of the muscle tissue was used to incubate with extracts of $D$. parishii (in a ratio of 19:1) at room temperature. The control group (muscle tissue) was incubated with $100 \mathrm{mM}$ Tris- $\mathrm{HCl}$ buffer ( $\mathrm{pH}$ 7.2) (in a ratio of 19:1, w/w). The incubation time was 2 hours. Oxidative stress biomarkers were studied in the incubated homogenate (control group and in the samples with extracts).

Determination of 2-thiobarbituric acid reactive substances (TBARS). The level of lipid peroxidation was determined by quantifying the concentration of TBARS by Kamyshnikov (2004) for determining the malonic dialdehyde (MDA) concentration. The concentration of MDA (nmol/mg of protein) was calculated using $1.5610^{5} \mathrm{mM}^{-1}$ $\mathrm{cm}^{-1}$ as the extinction coefficient [13].

The carbonyl derivatives content of protein oxidative modification (OMP) assay. To evaluate the protective effects of the extract against free radical-induced protein 
damage, a carbonyl derivatives content of protein oxidative modification (OMP) assay based on the spectrophotometric measurement of aldehydic and ketonic derivatives in the samples was performed. The rate of protein oxidative destruction was estimated from the reaction of the resultant carbonyl derivatives of amino acid reaction with 2,4dinitrophenylhydrazine (DNFH) as described by Levine and co-workers (1990) [16] and as modified by Dubinina and co-workers (1995) [7]. Carbonyl groups (nmol per mg of protein) were determined spectrophotometrically from the difference in absorbance at $370 \mathrm{~nm}$ (aldehydic derivatives, $\mathrm{OMP}_{370}$ ) and $430 \mathrm{~nm}$ (ketonic derivatives, $\mathrm{OMP}_{430}$ ).

Measurement of total antioxidant capacity $(\boldsymbol{T A C})$. The TAC level in the sample was estimated by measuring the 2-thiobarbituric acid reactive substances (TBARS) level after Tween 80 oxidation. This level was determined spectrophotometrically at 532 $\mathrm{nm}$ by Galaktionova and co-workers (1998) [8]. Sample inhibits the $\mathrm{Fe}^{2+} /$ ascorbateinduced oxidation of Tween 80, resulting in a decrease in the TBARS level. The level of TAC in the sample (\%) was calculated concerning the absorbance of the blank sample.

Statistical analysis. The mean \pm S.E.M. values were calculated for each group to determine the significance of the intergroup difference. All variables were tested for normal distribution using the Kolmogorov-Smirnov and Lilliefors test ( $p>0.05)$. The significance of differences (significance level, $\mathrm{p}<0.05$ ) was examined using the MannWhitney $U$ test [27]. All statistical calculation was performed on separate data from each individual with STATISTICA 8.0 software (StatSoft, Krakow, Poland).

Results and discussion. In the current study, we have evaluated the effect of extracts derived from the leaves and pseudobulbs of $D$. parishii on the level of oxidative stress biomarkers (TBARS level as biomarker of lipid peroxidation, aldehydic and ketonic derivatives of oxidatively modified proteins and the total antioxidant capacity) in the muscle tissue of rainbow trout treated by this extract. The negligible increase in TBARS level (by $13.3 \%$ and $4.5 \%, \mathrm{p}>0.05$ ) in the muscle tissue treated by extracts derived from leaves and pseudobulbs of $D$. parishii respectively compared to untreated control samples was observed (Fig. 1A, B).

In our study, the level of aldehydic derivatives of oxidatively modified proteins was non-significantly changed in the muscle samples incubated with extracts obtained from the leaves and pseudobulbs of D. parishii (by $3.5 \%$ and $3.7 \%, \mathrm{p}>0.05$, respective1y). Moreover, the level of ketonic derivatives of oxidatively modified proteins was non-significantly decreased by $7.3 \%$ ( $p>0.05$ ) both for leaf and pseudobulb extracts compared to the untreated samples (Fig. 1).

The total antioxidant capacity (TAC) determines the ability of a tested material to neutralize oxygen-free radical specific form, irrespectively to the specific antioxidant activity of present antioxidants [33]. Our results revealed that the extracts obtained from leaves and pseudobulbs of $D$. parishii significantly increased the TAC level in muscle tissue (by $53.2 \%$ and $74.8 \%, \mathrm{p}<0.05$, respectively) due to inhibited the $\mathrm{Fe}^{2+} /$ ascorbateinduced oxidation of Tween 80 . We suggested that increased TAC level is determined by the high content of by-products.

Among the Dendrobium species, possessing a broad spectrum of pharmacological activities most studies have been focused on the bioactivity and structural types of various compounds (alkaloids, flavonoids, phenolics, glycosides, polysaccharides, etc.) $[11,24,31]$. It was assumed that among all secondary metabolites, phenolic antioxidants appear to be the most important since they have shown promising antioxidant activity in both in vivo and in vitro studies [14]. Many published reports have demonstrated that polysaccharides, the major active constituents in Dendrobium, have beneficial activities in antioxidant, immune-stimulating, and antitumor activities. Polysaccharides from some Dendrobium species have been studied, such as D. officinale Kimura \& 
Migo (syn. D. huoshanense) and Dendrobium chrysotoxum Lindl. [19]. Alkaloids exhibit antioxidant, anticancer, and neuroprotective activities. Other compounds manifest antioxidant, anticancer, and immunomodulatory potential [21].

Many studies confirmed the antioxidant properties of Dendrobium plants. Antioxidant properties of crude extract, partition extract, and fermented medium from Dendrobium 'Sabin Blue' flower were investigated by Abu and co-workers (2017). The $100 \%$ methanolic crude extract showed the highest total phenolic content and the best antioxidant properties. $D$. 'Sabin Blue' flower exhibited very good potential properties of antioxidants in crude extract and partition extract as well as better antioxidant activity in the flower fermented medium [1]. Additionally, the protective effects of $D$. officinale extract (DOE) have been indicated in rat models against ischemia reperfusion-induced arrhythmia [28].

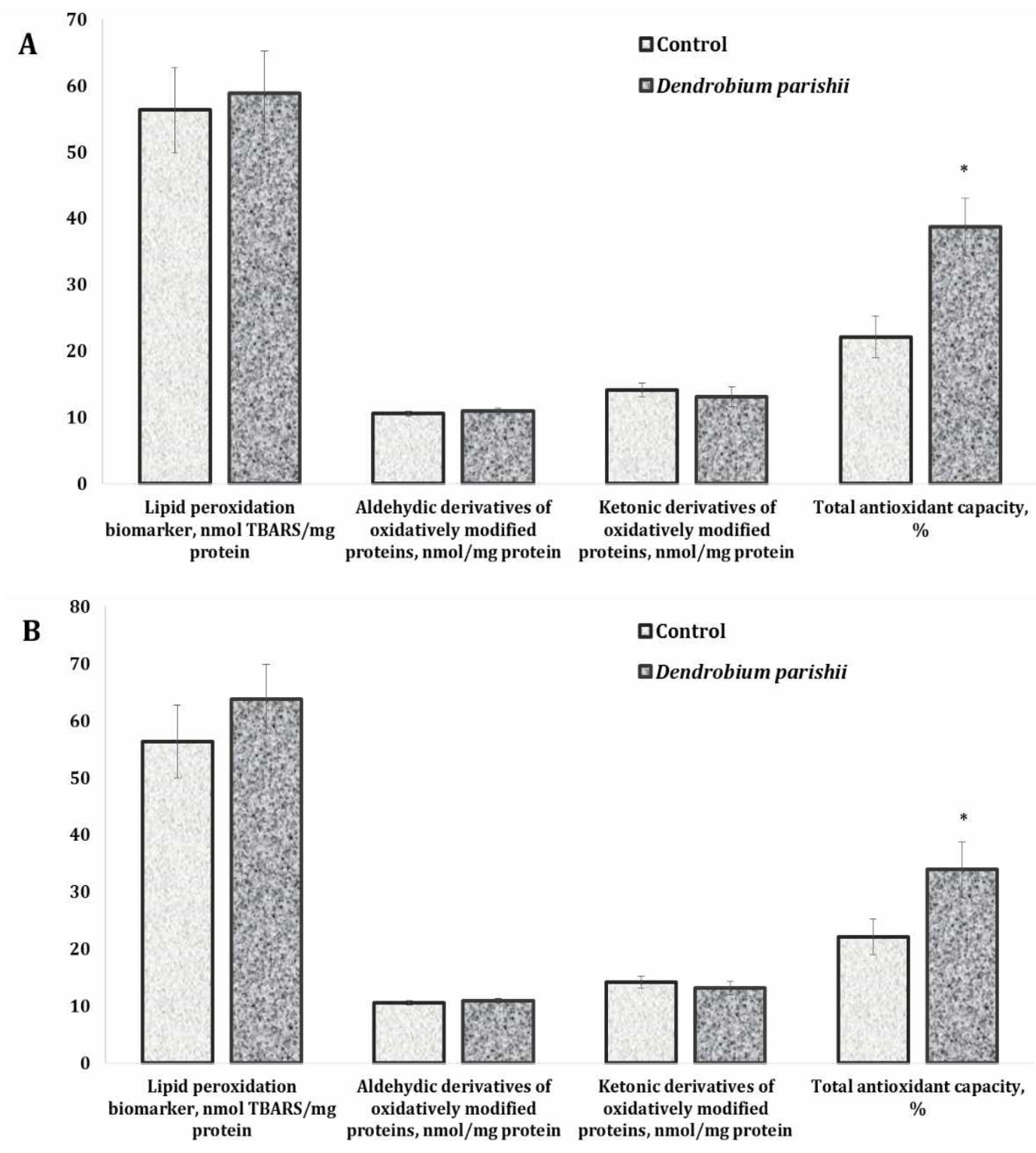

Fig. 1. TBARS level as biomarker of lipid peroxidation, aldehydic and ketonic derivatives of oxidatively modified proteins, and the total antioxidant capacity in the muscle tissue of rainbow trout treated by extracts derived from the leaves (A) and pseudobulbs (B) of Dendrobium parishii $(\mathbf{M} \pm \mathbf{m}, \mathbf{n}=8)$.

* - the changes are statistically significant $(\mathrm{p}<0.05)$ compared to the control group. 
Recently, D. officinale has been highlighted for its neuroprotective effects in an animal model [17]. It was revealed, that the aqueous extract of $D$. officinale can suppress the neuronal apoptosis and enhance the expression of neurotrophic factors to protect against hypoxic-ischemic brain damage (HIBD), induced in neonatal rats [17]. It is believed that Dendrobium alkaloids (DNLA) can exert neuroprotective effects against oxygen-glucose deprivation/reperfusion (OGD/R) damage in vitro, but the mechanisms underlying these effects remain uncertain. Liu and co-workers (2020) have investigated whether Dendrobium alkaloids (DNLA) exerted therapeutic effects against cerebral ischemia-reperfusion (CIR) damage via ameliorating pyroptosis and inflammation [18]. As a result, it was revealed that DNLA can protect against (CIR) damage through inhibiting pyroptosis-induced neuronal death. Thus, these findings demonstrate that aqueous extract of $D$. officinale affects various phases of damage including the early phase of oxidative stress and apoptosis as well as late-phase inflammatory reaction and neural repair, providing new therapeutic insights for hypoxic-ischemic brain damage (HIBD) [18].

The protective effects of $D$. officinale polysaccharides against $\mathrm{H}_{2} \mathrm{O}_{2}$-induced injury in $\mathrm{H} 9 \mathrm{c} 2$ cells were demonstrated. The results also indicated the anti-oxidative capability of D. officinale polysaccharides. Zhao and co-workers (2017) have studied the protective effect of $D$. officinale polysaccharides against $\mathrm{H}_{2} \mathrm{O}_{2}$-induced oxidative stress in H9c2 cells. MTT assay was carried out to determine the cell viability of H9c2 cells when pretreated with $D$. officinale polysaccharides. Fluorescent microscopy measurements were performed for evaluating the apoptosis in H9c2 cells. Furthermore, the effects of $D$. officinale polysaccharides on the activities of antioxidative indicators (malondialdehyde, superoxide dismutase), reactive oxygen species (ROS) production, and mitochondrial membrane potential (MMP) levels were analyzed. D. officinale polysaccharides attenuated $\mathrm{H}_{2} \mathrm{O}_{2}$-induced cell death, as determined by the MTT assay. D. officinale polysaccharides decreased malonic dialdehyde levels, increased superoxide dismutase activities, and inhibited the generation of intracellular ROS. Moreover, pretreatment with $D$. officinale polysaccharides also inhibited apoptosis and increased the MMP levels in $\mathrm{H} 9 \mathrm{c} 2$ cells [32].

HPLC-profiling of metabolites extracted from Dendrobium parishii seeds was undertaken by Buyun and Grakhov (2014). It was revealed that seeds of this species comprise, together with phenolics, the low polar inhibitors, apparently, also terpenoid or steroid derivatives [4]. Phytochemical screening of the leaf extracts of D. parishii has been conducted by Ivannikov and co-workers (2019a). It was established that the phenolic acids and flavonoids in the glycoside form were the main groups of bioactive compounds revealed in the extracts. Moreover, these researches have employed nanotechnology to produce composites for delayed release of bioactive compounds using D. parishii leaf extracts and fumed silica [12].

A polysaccharide is the main active ingredient in $D$. officinale; its antioxidant activity is a hot research topic nowadays. The antioxidant activities of the polysaccharide in vitro assay indicate that the $D$. officinale polysaccharide has a good scavenging activity of 1,1-diphenyl-2-picrylhydrazyl (DPPH) radical, higher scavenging activity of hydroxyl radical, and metal chelating activities [20]. Zhang and co-workers (2017) have adopted a model of $\mathrm{H}_{2} \mathrm{O}_{2}$-induced $\mathrm{H} 9 \mathrm{c} 2$ cardiomyocytes apoptosis, aiming to study the effect of D. officinale Polysaccharide (DOP-GY) for cardiomyocyte apoptosis caused by oxidative stress and its possible mechanism. The pretreatment of DOP-GY (low dose: $6.25 \mu \mathrm{g} / \mathrm{mL}$, medium-dose: $12.5 \mu \mathrm{g} / \mathrm{mL}$, high dose: $25 \mu \mathrm{g} / \mathrm{mL}$ ) followed by a $2 \mathrm{~h}$ incubation with $200 \mu \mathrm{M} \mathrm{H}_{2} \mathrm{O}_{2}$ elevated the survival rate, cut the lactate dehydrogenase (LDH) leakage, reduced lipid peroxidation damage, improved the activity of the endog- 
enous antioxidant enzymes. Also, the pretreatment of DOP-GY significantly inhibited the production of ROS, declined the mitochondrial membrane potential, down-regulated pro-apoptosis protein, and up-regulated anti-apoptosis protein. The protective effect was correlated with the PI3K/Akt and MAPK signal pathway. The study of Zhang and coworkers (2017) suggests that DOY-GY has the potential to exert cardioprotective effects against $\mathrm{H}_{2} \mathrm{O}_{2}$-induced $\mathrm{H} 9 \mathrm{c} 2$ cardiomyocyte apoptosis [29].

The potential of Dendrobium catenatum (D. officinale) flowers as a new antioxidant resource for medicinal and food products. The study of Zhang and coworkers (2019) has aimed to investigate the markers and their antioxidant activities in methanolic extracts of $D$. catenatum flowers and to establish the quality evaluation methods for raw materials and their products of the flower by HPLC [31]. The methanolic extract of 11 strains of $D$. catenatum flowers was found to contain a high content of total phenol and flavonoids, and they possessed potential antioxidant capacities based on DPPH radical scavenging assay. A total of 21 phenolic herb-markers were selected according to the similarity and principal component analysis of the chromatographic fingerprinting profiles. The identified compounds included 2 phenylpropanoids, 11Cglycosylflavones, and 6 O-glycosylflavones, which could be employed as the indicators for quantitative evaluation of the quality and authenticity of the flowers. Based on the pre-column DPPH/ABTS+-HPLC analysis, the major compounds contributed to the antioxidative activity were identified as 1-O-caffeoyl- $\beta$-D-glucoside, rutin, and isoquercitrin, all of which, was also the most abundant constituents in the methanolic extract [31].

Different molecular weight polysaccharides of $D$. officinale (DOPs) have gradually attracted attention because of their broad biological activities. The results of Zhang and co-workers (2019) demonstrated that DOPs can be used as the potential natural antioxidant and antitumor products in pharmaceutical industries, and the molecular weight is a crucial influential factor of their antitumor activity that $28.48 \mathrm{kDa}-176.29 \mathrm{kDa}$ is a suitable range. With the concentration increase of DOPs, the scavenging capacity against $\mathrm{OH}$ and DPPH free radicals increased. The antitumor ability of DOPs was different that DOP1-DOP5 (Mw: $176.29 \mathrm{kDa}-28.48 \mathrm{kDa}$ ) exhibited the best antiproliferation activity than DOP (Mw: 652.29 kDa) and DOP6 (Mw: 11.10 kDa) in HeLa cells rather than PC9, A549, and HepG2 cells. Moreover, DOP1 and DOP5 showed stronger capability on inducing apoptosis of HeLa cells than DOP and DOP6 via the mitochondrial pathway by upregulating the ratio of the Bax/Bal-2 mRNA expression [30].

The aqueous extract of $D$. officinale can suppress the neuronal apoptosis and enhance the expression of neurotrophic factors to protect neonatal rats against hypoxicischemic brain damage (HIBD). Li and Hong (2020) have hypothesized that D. officinale aqueous extract exerted neuroprotection against brain damage. Initially, a model of HIBD was induced in neonatal rats, which were subsequently intragastrically administered with different doses of $D$. officinale aqueous extract. Next, the antioxidant capacity was examined by enzyme-linked immunosorbent assay. 2,3,5-Triphenyltetrazolium chloride and terminal deoxynucleotidyl transferase-mediated dUTP nick end-labeling staining assays were adopted to determine neuronal apoptosis in brain tissues. Furthermore, neurotrophic factors and hypoxia-inducible factor- $1 \alpha$ (HIF-1 $\alpha$ ) expression were identified by Western blot analysis. The neonatal rat models of HIBD presented impaired neurobehaviors and antioxidant capacity, increased neuronal apoptosis, and expression of HIF-1 $\alpha$ and histone deacetylase 1 (HDAC1), as well as diminished expression of neurotrophic factors and $\mathrm{K}^{+}-\mathrm{Cl}^{-}$-cotransporter 2 (KCC2). Notably, in response to different doses of $D$. officinale aqueous extract, the impairment on neurobehaviors and antioxidant capacity was alleviated, accompanied by reduced levels of nitric oxide syn- 
thase, nitric oxide, and malondialdehyde, and increased superoxide dismutase activity. Besides, the neuronal apoptosis was inhibited as reflected by down-regulated cleaved caspase-3 and Bax and up-regulated Bcl-2. Moreover, Li and Hong (2020) also found accelerated expression of neurotrophic factors and $\mathrm{KCC} 2$ and diminished expression of HIF- $1 \alpha$ and HDAC1 [17].

The role of $D$. officinale polysaccharides (DOPs) in age-related osteoporosis was studied by Peng and co-workers (2019). Oxidative stimulation and DOP were used to treat bone marrow mesenchymal stem cells (BMSCs), whose lineage commitment was measured by adipogenic- and osteoblastic-induced differentiation analysis. The oxidative stress and antioxidant capacity of BMSCs under the treatment of DOP were analyzed by the level of MDA, SOD. Related mechanism studies were confirmed by qRTPCR, Western blotting, and siRNA transfection. DOP was orally administrated in aged mice whose phenotype was confirmed by micro-CT, immunofluorescence, immunocytochemistry, and calcein double-labeling analysis. D. officinale polysaccharide treatment markedly increased osteogenic differentiation of BMSCs, while inhibiting adipogenic differentiation. In vitro, DOP could rescue $\mathrm{H}_{2} \mathrm{O}_{2}$-induced switch of BMSCs differentiation fate. However, this effect was abolished in BMSCs when interfered with Nrf2 siRNA. Furthermore, the administration of DOP to aged mice significantly increased the bone mass and reduced the marrow adipose tissue (MAT) accompanied by decreased oxidative stress of BMSCs. The study of Peng and co-workers (2019) revealed that DOP can attenuate bone loss and MAT accumulation through NRF2 antioxidant signaling, which may represent a potential therapeutic agent for age-related osteoporosis [25].

Currently, several in vitro and in vivo methods have been used to screen plants for their antioxidant properties. Nevertheless, despite many plant species being reported to have antioxidant potential observed with in vitro assays, only a few of these antioxidant activities have been confirmed or investigated in vivo $[2,14]$.

Conclusions. In this study, both leaf and pseudobulbs extracts of $D$. parishii have induced the increase in the total antioxidant capacity in the muscle tissue of the rainbow trout. The TBARS content as a biomarker of lipid peroxidation, as well as aldehydic and ketonic derivatives level, was non-significantly altered. Screening of Dendrobium plants for other biological activities including antioxidant properties is essential and may be effective for searching the preventive agents in the aquaculture. However, to avoid misinterpretation of these findings, the antioxidant potential of Dendrobium plant species should be assessed based on both in vitro and in vivo assays.

\section{References}

1. Abu, F., Mat Taib, C. N., Mohd Moklas, M. A., \& Mohd Akhir, S. (2017). Antioxidant Properties of Crude Extract, Partition Extract, and Fermented Medium of Dendrobium sabin Flower. Evid. Based Complement. Alternat. Med., 2907219.

2. Alam, M. N., Bristi, N. J., \& Rafiquzzaman, M. (2013). Review on in vivo and in vitro methods evaluation of antioxidant activity. Saudi Pharm. J., 21(2), 143152.

3. Buyun, L., Tkachenko, H., Kurhaluk, N., Gyrenko, O., Kovalska, L., \& Osadowski, Z. (2019). Assessment of oxidative stress biomarkers in the equine blood after in vitro incubation with leaf extract obtained from Dendrobium parishii Rchb.F. Agrobiodiversity for Improving Nutrition, Health, and Life Quality, 3, 416-427.

4. Buyun, L. I., \& Grakhov, V. P. (2014). Bioactivity of some orchid seeds substances and secondary metabolites composition. Proceedings of the 2-nd Russian Conference with international participation dedicated to the memory of Professor A. P. Me- 
likiann «Carpology and reproductive biology of higher plants». (1-3 October 2014), (pp. 188-194). Moscow.

5. Cheng, J., Dang, P. P., Zhao, Z., Yuan, L. C., Zhou, Z. H., Wolf, D., \& Luo, Y. B. (2019). An assessment of the Chinese medicinal Dendrobium industry: Supply, demand and sustainability. J. Ethnopharmacol., 229, 81-88.

6. Citarasu T. (2010). Herbal biomedicines: a new opportunity for aquaculture industry. Aquac. Int., 18, 403-414.

7. Dubinina, E. E., Burmistrov, S. O., Khodov, D. A., \& Porotov, I. G. (1995). Oxidative modification of human serum proteins. A method of determining it. Voprosy Meditsinskŏ Khimii, 41, 24-26 [in Russian].

8. Galaktionova, L. P., Molchanov, A. V., El'chaninova, S. A., \& Varshavski1, Bla. (1998). Lipid peroxidation in patients with gastric and duodenal ulcers. Klinicheskaia Labaratornaia Diagnostika, 6, 10-14 [in Russian].

9. Galina, J., Yin, G., Ardó, L., \& Jeney, Z. (2009). The use of immunostimulating herbs in fish. An overview of research. Fish Physiol. Biochem., 35(4), 669-676.

10. Harikrishnan, R., Balasundaram, C., \& Heo, M.-S. (2011). Impact of plant products on innate and adaptive immune system of cultured finfish and shellfish. Aquaculture, 317, 1-15.

11. Honda, C., \& Yamaki, M. (2000). Phenanthrenes from Dendrobium plicatile. Phytochemistry, 53(8), 987-990.

12. Ivannikov, R. V., Laguta, I. V., Stanislavskaya, O. N., Anishchenko, V. M., Buyun, L. I., \& Pakhlov, E. M. (2019). Composites for prolonged release of bioactive compounds based on orchid leaves extracts and fumed silica. Dopov. Nac. Akad. Nauk $U k r$. 4, 66-73. [in Ukrainian]

13. Kamyshnikov, V. S. (2004). A reference book on the clinic and biochemical researches and laboratory diagnostics. MEDpress-inform, Moscow.

14. Kasote, D. M., Katyare, S. S., Hegde, M. V., \& Bae, H. (2015). Significance of antioxidant potential of plants and its relevance to therapeutic applications. Int. J. Biol. Sci., 11(8), 982-991.

15. Lee, C. T., Kuo, H. C., Chen, Y. H., \& Tsai, M. Y. (2018). Current Advances in the Biological Activity of Polysaccharides in Dendrobium with Intriguing Therapeutic Potential. Curr. Med. Chem., 25(14), 1663-1681.

16. Levine, R. L., Garland, D., Oliver, C. N., Amic, A., Climent, I., Lenz, A. G., Ahn, B. W., Shaltiel, S., \& Stadtman, E. R. (1990). Determination of carbonyl content in oxidatively modified proteins. Methods in Enzymology, 186, 464-478.

17. Li, X. L., \& Hong, M. (2020). Aqueous extract of Dendrobium officinale confers neuroprotection against hypoxic-ischemic brain damage in neonatal rats. Kaohsiung J. Med. Sci., 36(1), 43-53.

18. Liu, D., Dong, Z., Xiang, F., Liu, H., Wang, Y., Wang, Q., \& Rao, J. (2020). Dendrobium Alkaloids Promote Neural Function After Cerebral IschemiaReperfusion Injury Through Inhibiting Pyroptosis Induced Neuronal Death in both In Vivo and In Vitro Models. Neurochem. Res., 45(2), 437-454.

19. Luo, A., He, X., Zhou, S., Fan, Y., He, T., \& Chun, Z. (2009). In vitro antioxidant activities of a water-soluble polysaccharide derived from Dendrobium nobile Lindl. extracts. Int. J. Biol.Macromol.,45(4), 359-363.

20. Luo, Q. L., Tang, Z. H., Zhang, X. F., Zhong, Y. H., Yao, S. Z., Wang, L. S., Lin, C. W., \& Luo, X. (2016). Chemical properties and antioxidant activity of a water-soluble polysaccharide from Dendrobium officinale. Int. J. Biol. Macromol., 89, 219-227. 
21. Ng, T. B., Liu, J., Wong, J. H., Ye, X., Wing Sze, S. C., Tong, Y., \& Zhang, K. Y. (2012). Review of research on Dendrobium, a prized folk medicine. Appl. Microbiol. Biotechnol., 93(5), 1795-1803.

22. Nie, J., Tian, Y., Zhang, Y., Lu, Y. L., Li, L. S., \& Shi, J. S. (2016). Dendrobium alkaloids prevent A $\beta 25$-35-induced neuronal and synaptic loss via promoting neurotrophic factors expression in mice. Peer J., 4, e2739.

23. Nie, X., Chen, Y., Li, W., Lu, Y. (2020). Anti-aging properties of Dendrobium nobile Lindl.: From molecular mechanisms to potential treatments. $J$. Ethnopharmacol., 257, 112839.

24. Paudel, M. R., Chand, M. B., Pant, B., Pant, B. (2018). Antioxidant and cytotoxic activities of Dendrobium moniliforme extracts and the detection of related compounds by GC-MS. BMC Complement. Altern. Med., 18(1), 134.

25. Peng, H., Yang, M., Guo, Q., Su, T., Xiao, Y., \& Xia, Z. Y. (2019). Dendrobium officinale polysaccharides regulate age-related lineage commitment between osteogenic and adipogenic differentiation. Cell Prolif., 52(4), e12624.

26. Yamashita, Y., Katagiri, T., Pirarat, N., Futami, K., Endo, M., \& Maita, M. (2009). The synthetic antioxifant, etoxyquin, adversely affects immunity in tilapia (Oreochromis niloticus). Aquaculture Nutrition, 15, 144-151.

27. Zar J. H. (1999). Biostatistical Analysis. $4^{\text {th }}$ ed., Prentice-Hall Inc., Englewood Cliffs, New Jersey.

28. Zhai, X. F., Wang, J., Zheng, S., \& Xiao, X. C. (2017). Protective effects of Dendrobium candidum on ischemia reperfusion-induced arrhythmia. Modern Food Science \& Technol., 33(7), 1-8.

29. Zhang, J. Y., Guo, Y., Si, J. P., Sun, X. B., Sun, G. B., \& Liu, J. J. (2017). A polysaccharide of Dendrobium officinale ameliorates $\mathrm{H}_{2} \mathrm{O}_{2}$-induced apoptosis in $\mathrm{H} 9 \mathrm{c} 2$ cardiomyocytes via PI3K/AKT and MAPK pathways. Int. J. Biol. Macromol., 104(Pt A), 1-10.

30. Zhang, X., Luo, Y., Wei, G., Li, Y., Huang, Y., Huang, J., Liu, C., Huang, R., Liu, G., Wei, Z., \& Du, S. (2019). Physicochemical and Antioxidant Properties of the Degradations of Polysaccharides from Dendrobium officinale and Their Suitable Molecular Weight Range on Inducing HeLa Cell Apoptosis. Evid. Based Complement. Alternat. Med., 2019: 4127360.

31. Zhang, X., Zhang, S., Gao, B., Qian, Z., Liu, J., Wu, S., \& Si, J. (2019). Identification and quantitative analysis of phenolic glycosides with antioxidant activity in methanolic extract of Dendrobium catenatum flowers and selection of quality control herb-markers. Food Res. Int., 123, 732-745.

32. Zhao, X., Dou, M., Zhang, Z., Zhang, D., \& Huang, C. (2017). Protective effect of Dendrobium officinale polysaccharides on $\mathrm{H}_{2} \mathrm{O}_{2}$-induced injury in $\mathrm{H} 9 \mathrm{c} 2$ cardiomyocytes. Biomed. Pharmacother., 94, 72-78.

33. Zheng, W., \& Wang, S. Y. (2003). Oxygen radical absorbing capacity of phenolics in blueberries, cranberries, chokeberries, and lingonberries. J. Agric. Food Chem., 51(2), 502-509. 
ДОСЛІДЖЕННЯ IN VITRO АНТИОКСИДАНТНОЇ АКТИВНОСТІ ВОДНИХ EКСТРАКТIВ ВЕГЕТАТИВНИХ ОРГАНIВ DENDROBIUM PARISHII RCHB.F. $У$ М'ЯЗОВІЙ ТКАНИНІ РАЙДУЖНӦ̈ ФОРЕЛI (ONCORHYNCHUS MYKISS WALBAUM)

Буюн Л., Гиренко О., Опришко М., Ковальська Л., Начіональний ботанічний сад імені М. М. Гришка, Національна академія наук України.

Ткаченко Г., Кургалюк Н., Інститут біологї̈ та наук про Землю, Поморська Академія у Слупську.

Метою даного дослідження було з'ясувати за умов in vitro особливості впливу буферних екстрактів листків та псевдобульб (видозмінених пагонів) Dendrobium parishii Rchb. f. шляхом оцінювання рівнів TBARS (речовин, щзо реагують з 2-тіобарбітуровою кислотою) як біомаркера ліпідної пероксидації, альдегідних та кетонових похідних оксидачійно модифікованих білків та загальної антиоксидантної активності (ТАС) у м'язовій тканині райдужної форелі (Oncorhynchus mykiss Walbaum). Пагони (nсевдобульби) з листям Dendrobium parishii, культивовані в тепличних умовах, були відібрані в Наџіональному ботанічному саду ім. М. М. Гришко (НБГ) (Київ, Україна). 31999 року вся колекція тропічних і субтропічних рослин (включаючи орхідеї) має статус начіонального надбання України і підтримується за рахунок державного фінансування. Крім того, колекиія тропічних орхідей НБГ була зареєстрована в адміністративному органі СІТЕС в Україні (Міністерство охорони навколишнього середовищз, реєстрачійний номер 6939/19/1-10 від 23 червня 2004 року). Зібрані псевдобульби $i$ листя приносили в лабораторію для біохімічних досліджень. Свіжозібране листя промивали, зважували, подрібнювали і гомогенізували в 0,1 м фосфатному буфері (pH 7,4) (в пропориіiі 1:19, Bm/Bm) при кімнатній температурі. Потім екстракт фільтрували і досліджували на його антиоксидантну здатність. Екстракт зберігали при температурі $-20{ }^{\circ} \mathrm{C}$ до використання. Було відмічено незначне підвищення рівнів TBARS у зразках м'язової тканини, інкубованої з екстрактами листків та псевдобульб D. parishii. Натомість, рівень альдегідних та кетонових похідних оксидаційно модифікованих білків за дії екстрактів, отриманих як із листків, так $i$ псевдобульб D. parishii, у порівнянні з контрольними зразками був несуттево знижений. Разом з тим, екстракти листків та псевдобульб D. parishii суттєво підвищували рівень загальної антиоксидантної активності (ТАC) у м'язовій тканині, про щчо свідчило інгібування Fе2+/аскорбат-ініційованого вільнорадикального окиснення Twеen 80. Загалом, ичі результати свідчать про те, щзо водні екстракти вегетативних органів D. parishii можуть підвищувати загальну антиоксидантну активність у зразках м'язової тканини райдужної форелі. Слід зазначити, щуо антиоксидантна дія, спричинена екстрактами псевдобульб D. parishii, виявилась інтенсивнішою.

Ключові слова: Dendrobium Sw., екстракти, антиоксидантна активність, м'язова тканина, райдужна форель (Oncorhynchus mykiss Walbaum) 
ИССЛЕДОВАНИЕ IN VITRО АНТИОКСИДАНТНОЙ АКТИВНОСТИ ВОДНЫХ ЭКСТРАКТОВ ВЕГЕТАТИВНИХ ОРГАНОВ DENDROBIUM PARISHII RCHB.F. В МЫШЕЧНОЙ ТКАНИ РАДУЖНОЙ ФОРЕЛИ (ONCORHYNCHUS MYKISS WALBAUM)

Буюн Л., Гиренко А., Опришко М., Ковальская Л., Национальный ботанический сад имени Н. Н. Гришко, Наџиональная академия наук Украиньл.

Ткаченко Г., Кургалюк Н., Институт биологии и наук о Земле, Поморская академия в Слупске, Польша.

Цель настоящей работы состояла в том, чтобы в условиях in vitro исследовать особенности влияния буферных экстрактов, полученных из листьев и псевдобульб (видоизмененных побегов) Dendrobium parishii Rchb. f., nутем определения TBARS (веществ, реагируюших с 2-тиобарбитуровой кислотой) как биомаркера липидной пероксидации, альдегидных и кетоновых производных окислительно модифицированных белков и общей антиоксидантной активности (ТАC) в мышечной ткани радужной форели (Oncorhynchus mykiss Walbaum). Побеги (nceвдобульбы) с листьями Dendrobium parishii, культивируемые в тепличных условиях, были отобраны в Национальном ботаническом саду им. М. М. Гришко (НБГ) (Киев, Украина). С 1999 года вся коллекиия тропических и субтропических растений (включая орхидеи) имеет статус начионального достояния Украины и поддерживается за счет государственного финансирования. Кроме того, коллекция тропических орхидей НБГ была зарегистрирована в административном органе СИТЕС в Украине (Министерство охраны окружающей среды, регистрационный номер 6939/19/1-10 от 23 июня 2004 года). Собранные псевдобульбы и листья приносили в лабораторию для биохимических исследований. Свежесобранные листья промывали, взвешивали, измельчали и гомогенизировали в 0,1 м фосфатном буфере $(\mathrm{pH} 7,4)$ (в пропориии 1:19, Bm/Bm) при комнатной температуре. Затем экстракт фильтровали и исследовали на его антиоксидантную способность. Экстракт хранили при температуре $-20{ }^{\circ} \mathrm{C}$ до использования. Было отмечено незначительное повышение уровней TBARS в образиах мышечной ткани, инкубированных с экстрактом листьев и псевдобульб D. parishii. C другой стороны, уровень альдегидных и кетоновых производных окислительно модифицированных белков под воздействием экстрактов, полученных как из листьев, так и псевдобульб D. parishii, был несущественно снижен по сравнению с контрольныли образиами. Экстракты листьев и псевдобульб D. parishii значительно повышали уровень общей антиоксидантной активности (ТАC) в мышечной ткани, о чем свидетельствовало ингибирование Fe2+/аскорбат-инициированного свободнорадикального окисления Tweеn 80. В иелом, эти результаты свидетельствуют о том, что водные экстракты вегетативных органов D. parishii способны повышать антиоксидантную способность в мылшечной ткани радужной форели. Следует отметить, что антиоксидантный эффрект, вызванный экстрактами псевдобульб D. parishii, был более интенсивным.

Ключевые слова: Dendrobium Sw., экстракты, антиоксидантная активность, мьлшечная ткань, радужная форель (Oncorhynchus mykiss Walbaum). 